\title{
PORTAL VEIN EMBOLIZATION USING AN ADAPTED HYSTEROSALPINGOGRAPHY CATHETER
}

\author{
Embolização portal utilizando cateter adaptado de histerossalpingografia
}

Klaus STEINBRÜCK${ }^{1}$, Jefferson ALVES ${ }^{2}$, Reinaldo FERNANDES ${ }^{1}$, Marcelo ENNE ${ }^{3}$ Lúcio Filgueiras PACHECO-MOREIRA ${ }^{4}$

From the ${ }^{1}$ Serviço de Cinurgia Hepato-Biliar, Hospital Federal de Bonsucesso, Ministério da Saúde, Rio de Janeiro; ${ }^{2}$ Programa de Transplantes, Hospital IsraelitaAlbertEinstein, São Paulo: ${ }^{3}$ Senviço de Cinurgia Geral, Hospital Federal de Ipanema, Ministério da Saúde, Rio de Janeiro; ${ }^{4}$ Programa Estadual de Transplantes, Hospital São Francisco de Assis, Rio de Janeiro (Hepato-Biliary Surgery Senvice, Federal Bonsucesso Hospital, Ministry of Health, Rio de Janeiro; ${ }^{2}$ Transplantation Program, Albert Einstein Jewish Hospital, São Paulo; ${ }^{3}$ General Surgery Senvice, Federal I Ipanema Hospital, Ministry of Health, Rio de Janeiro; ${ }^{4}$ Transplantation Program, São Francisco de Assis Hospital, Rio de Janeiro), Brazil.

HEADINGS - Transplantation. Disease. General surgery.

\section{Correspondence:}

Klaus Steinbrück

E-mail:steinbruck@gmail.com

Financial source: none

Conflicts of interest: none

Received for publication: 27/01/2014

Accepted for publication: 16/04/2014

DESCRTORES - Transplante. Doença. Cirurgia Geral.
ABSTRACT - Background: Portal vein embolization is an accepted procedure that provides hypertrophy of the future remnant liver in order to reduce posthepatectomy complications. Aim: To present a series submitted to portal vein embolization using an adapted hysterosalpingography catheter via transileocolic route. Methods: Were performed right portal branch embolization in 19 patients using hysterosalpingography catheter. For embolizing the vessel, was used Gelfoam ${ }^{\circledR}$ powder with absolute alcohol solution. Indications for hepatectomy were colorectal liver metastases in all cases. Results: An adequate growth of the future remnant liver was achieved in 15 patients (78.9\%) and second time hepatectomy could be done in 14 (73.7\%). In one patient (5.2\%), tumor progression prevented surgery. One patient presented acute renal failure after portal embolization. Conclusions: The hysterosalpingography catheter is easy to handle and can be introduced into the portal vein with a wire guide. There were no major postembolization complication. Its use is safe, cheap and effective.

INTRODUCTION

A dvances in hepatic surgery have reduced the mortality rate after major liver resection but complications resulting from inadequate postresection hepatic function and size remain. Portal vein embolization is an accepted and useful procedure that provides hypertrophy of the future remnant liver in order to reduce such complications. Even though percutaneous transhepatic portal vein embolization is the most used technique ${ }^{3}$; there is still place for portal vein embolization via transileocolic route, especially in hospitals were interventional radiology is not available.

The objective of this study was to demonstrate one series of portal vein embolization performed through transileocolic approach, using an adapted hysterosalpingography catheter.

METHODS

Was performed portal vein embolization in 19 patients using an adapted $5 F \times 40 \mathrm{~cm}$ hysterosalpingography catheter (Angiotech Medical Device Technologies, Inc., 3600 S.W. 47th Avenue Gainesville, Florida 32608 USA - Figure 1A) to stimulate growth of the future remnant liver. Indications for hepatectomy were colorectal liver metastases in all cases. The procedure was executed via transileocolic route after minilaparotomy in all patients.

Once the catheter was placed in the portal vein, its position was confirmed by fluoroscopy and the catheter balloon (Figures $1 \mathrm{~B}$ and $1 \mathrm{C}$ ) was insufflated to occlude the right portal branch (Figure 2). For embolizing the vessel, was used Gelfoam ${ }^{\circledR}$ powder with absolute alcohol solution $(0,5 \mathrm{ml} / \mathrm{kg})$. 
An adequate growth of the future remnant liver was achieved in 15 patients (78.9\%) and hepatectomy could be done in 14 (73.7\%), eight to ten weeks after portal vein embolization. Four patients $(21.1 \%)$ did not present a satisfactory growth of the future remnant liver, and surgery was cancelled. In one patient (5.2\%), local intrahepatic tumor progression prevented second surgery. One patient had acute renal failure after the embolization procedure, but no dialysis was needed. All patients reported, after the end of anesthesia, a feeling of hangover.

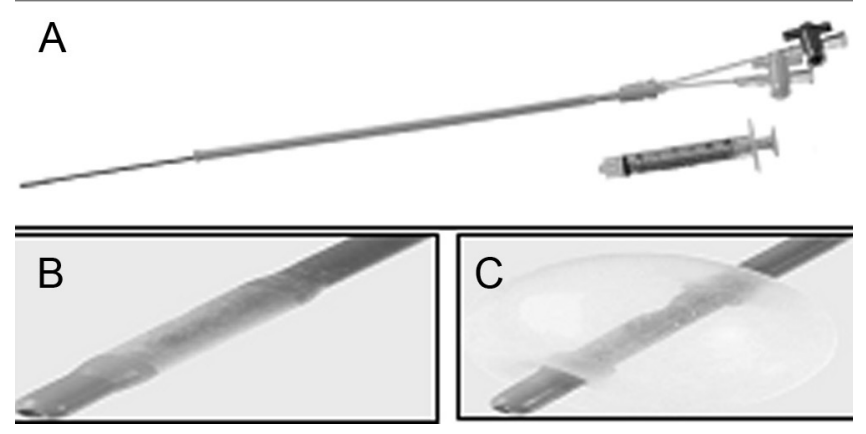

FIGURE 1 - A) Hysterosalpingography catheter; B and C) the balloon system

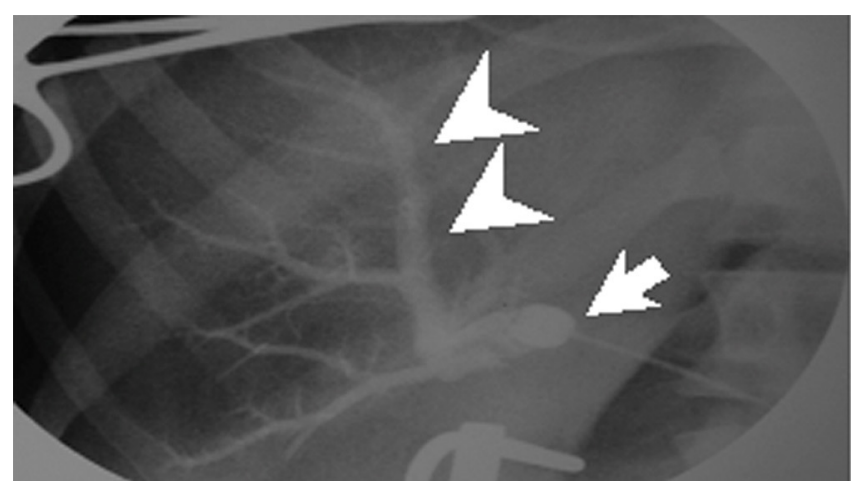

FIGURE 2 - Fluoroscopy image showing the insufflated balloon (arrow) and the embolized right portal branch (arrow heads)
Portal vein embolization is a recognized procedure that provides growth of the future remnant liver, thereby sustaining the possibility of extensive liver resection in patients with a predictable insufficient remnant liver volume. A recent review carried out by van Lienden et al. ${ }^{3}$ showed that $12,4 \%$ of portal vein embolization are still been done via transileocolic route. This fact could be justified in part by difficulties to access radiological intervention facilities to do the percutaneous approach, which is the case of our hospital. To guarantee an adequate treatment, was adapted a hysterosalpingography catheter to perform portal vein embolization. It is a balloon catheter system described by Sholkoff in $1987^{2}$. It is easy to handle and can be introduced into the portal vein with a wire guide. It is not an expensive device (US\$ 6 per unit) and the diameter of its balloon is $10 \mathrm{~mm}$, got with $0.8 \mathrm{ml}$ of saline solution, providing an effective occlusion of the right portal branch to avoid non target vessels embolization. The success rate here presented to indicate secondary hepatectomy was $73.7 \%$, which is similar to literature rate $(80 \%)^{3}$. According to Clavien's scoring system ${ }^{1}$, there was no major postembolization complication. It is important to mention that the open approach allows an assessment of the peritoneal cavity at the time of portal vein embolization to observe the liver lesion and the presence of local affections.

\section{CONCLUSION}

The hysterosalpingography catheter is easy to handle and can be introduced into the portal vein with a wire guide. There were no major post-embolization complication. Its use is safe, cheap and effective.

\section{REFERENCES}

1. Clavien PA, Camargo CA, Croxford R, Langer B, Levy GA, Greig PD. Definition and classification of negative outcomes in solid organ transplantation: application in liver transplantation. Ann Surg 1994; 220:109-120.

2. Sholkoff SD. Balloon Hysterosalpingography Catheter. AJR 1987;149:995-996.

3. van Lienden $\mathrm{KP}$, van den Esschert JW, de Graaf W, Bipat S, Lameris JS, van Guliket TM, et al. Portal Vein Embolization Before Liver Resection: A Systematic Review. Cardiovasc Intervent Radiol 2013;36:25-34. 